GRASAS Y ACEITES 68 (3)

July-September 2017, e212

ISSN-L: 0017-3495

doi: http://dx.doi.org/10.3989/gya.0219171

\title{
Hypocholesterolemic impact of newly isolated sophorolipids produced by microbial conversion of safflower oil cake in rats fed high-fat and cholesterol diet
}

\author{
M.U. Nooman ${ }^{\mathrm{a}}$, M.H. Mahmoud ${ }^{\mathrm{b}}$, A.S. Al-kashef ${ }^{\mathrm{a}}$ and M.M. Rashad ${ }^{\mathrm{a}, \bigotimes}$ \\ ${ }^{a}$ Biochemistry Department, Division of Genetic Engineering and Biotechnology, National Research Centre, Cairo, Egypt \\ ${ }^{b}$ Department of Nutrition and Food Sciences, Division of Food Industries and Nutrition, National Research Centre, Cairo, Egypt \\ ${ }^{\square}$ Corresponding author: monarashad122@gmail.com
}

Submitted: 14 February 2017; Accepted: 07 June 2017

SUMMARY: The present study aims to produce low cost sophorolipids, and to evaluate their potential hypocholesterolemic impact. Sophorolipids were produced by Candida bombicola grown on safflower oil cake, extracted by methanol followed by ethyl acetate with a yield of 24.4 and $48.3 \mathrm{~g} \cdot 100 \mathrm{~g}^{-1}$ mixed substrate, respectively. Their structure was confirmed by FTIR and ${ }^{1} \mathrm{H}$ NMR and proven to be safe when subjected to an acute toxicity test. A biological experiment was done on 42 male albino rats classified into six groups for 4 weeks following an induction period for hypercholesterolemia of 8 weeks. The two extracts and their mixture were examined for their hypocholesterolemic effect compared to rosuvastatin. The results revealed a reduction in total cholesterol, low density lipoprotein cholesterol, atherogenic index, liver transaminases' activity and malondialdehyde. They also revealed an elevation in high density lipoprotein cholesterol and antioxidant enzymes which was more efficient than rosuvastatin. Histopathological examination confirmed these results. In conclusion, the newly isolated sophorolipids are powerful hypocholesterolemic compounds which are even more efficient and safer than rosuvastatin.

KEYWORDS: Candida bombicola; Hypocholesterolemic; Lipid profile; Rats; Safflower oil cake; Solid state fermentation; Sophorolipids

RESUMEN: Efecto hipocolesterolémico de soforolípidos recién aislados producidos por la conversión microbiana de la torta de aceite de cártamo en ratas alimentadas con una dieta rica en grasas y colesterol. El presente estudio tiene como objetivo producir soforolípidos de bajo costo, evaluando su potencial impacto hipocolesterolémico. Los soforolípidos fueron producidos por Candida bombicola cultivada en torta de aceite de cártamo, extraída con metanol seguido de acetato de etilo con un rendimiento de 24,4 y 48,3 g $100 \mathrm{~g}^{-1}$ de sustrato mixto, respectivamente. Su estructura fue confirmada por FTIR y ${ }^{1} \mathrm{H}$ RMN y demostró ser segura cuando se sometió a prueba de toxicidad aguda. Un experimento biológico se realizó con 42 ratones albinos machos clasificados en seis grupos, durante 4 semanas, después de un período de inducción al hipercolesterolemia de 8 semanas. Se examinaron los dos extractos y su mezcla para determinar su efecto hipocolesterolémico en comparación con rosuvastatina. Los resultados revelaron una reducción en el colesterol total, el colesterol de lipoproteínas de baja densidad, el índice aterogénico, la actividad de las transaminasas hepáticas y el malondialdehído, mientras que mostraron una elevación del colesterol de lipoproteínas de alta densidad y de las enzimas antioxidantes más eficientemente que la rosuvastatina. El examen histopatológico confirmó estos resultados. En conclusión, los soforolípidos recién aislados son potentes compuestos hipocolesterolémicos aún más eficientes y más seguros que la rosuvastatina.

PALABRAS CLAVE: Candida bombicola; Fermentación en estado sólido; Hipocolesterolémico; Perfil lipídico; Ratas; Soforolípidos; Torta de aceite de cártamo

ORCID ID: Nooman MU https://orcid.org/0000-0001-6324-5601, Mahmoud MH https://orcid.org/0000-0002-27825200, Al-kashef AS https://orcid.org/0000-0003-2256-5136, Rashad MM http://orcid.org/0000-0002-3657-2102

Citation/Cómo citar este artículo: Nooman MU, Mahmoud MH, Al-kashef AS, Rashad MM. 2017. Hypocholesterolemic impact of newly isolated sophorolipids produced by microbial conversion of safflower oil cake in rats fed on high fat and cholesterol diet. Grasas Aceites 68 (3), e212. http://dx.doi.org/10.3989/gya.0219171

Copyright: (C2017 CSIC. This is an open-access article distributed under the terms of the Creative Commons Attribution (CC-by) Spain 3.0 License. 


\section{INTRODUCTION}

Atherosclerosis is the principal contributor to the pathogenesis of myocardial and cerebral infarctions. It is known to be one of the leading causes of morbidity and mortality worldwide (Uhegbu et al., 2013). The etiology of atherosclerosis is multi-factorial; hypercholesterolemia is one of these factors (Jegadeesh et al., 2014).

Most of the commonly used hypocholesterolemic drugs have undesirable side effects. Statins as a new generation of hypocholesterolemic drugs are widely used to lower cholesterol, preventing the risk of coronary heart disease. They work as mevalonate pathway inhibitors, thus blocking cholesterol synthesis. The most common side effect of statins is related to the depletion of the coenzyme Q10 which is used for energy production by body cells (Graveline, 2015). Consequently, there has been an increased interest in creating natural products for the production of hypocholesterolemic drugs with lower adverse effects.

Amphiphilic compounds have been found to have interesting applications, due to their ability to form surface and emulsifying activities. They are classified as bio-surfactants, and used in medicine for their antimicrobial, antiviral and potential anticancer activities. Different types of bio-surfactants have been reported, such as glycolipids, lipopeptides, polysaccharide-protein complexes, phospholipids, fatty acids and neutral lipids (Wang et al., 2007; Rashad et al., 2014a). This wide range in the chemical structure of different groups of bio-surfactants allowed them to be reasonable for exerting diverse properties and physiological functions. Furthermore, the characterization of being effective at extreme $\mathrm{pH}$ values or temperatures, lower toxicity and higher biodegradability make bio-surfactants suitable and favorable over the chemical surfactants in environmental applications (Rashad et al., 2014b).

Industrial food wastes are cheap and good sources of nutrients and minerals. They can be used as a substrate for the production of low priced bioactive materials (Daverey and Pakshirajan, 2009). The industry of edible fats and lipids generates great amounts of oil waste, for example fatty acids and oil cakes. Plants constitute about $75 \%$ of the worldwide production of oils and fats (Haba et al., 2000); one of these wastes is safflower oil cake which is a residue from the pressed seeds after oil extraction. Previously sunflower oil cake has been employed for the production of bio-surfactants (Rashad et al., 2014a).

Bio-surfactants are produced by microorganisms such as Bacillus subtilis, Renibacterium salmoninarum, Pseudomonas aeruginosa, Pseudomonas putida, Pseudomonas chlororaphis, Candida bombicola and
Candida apicola. They contain hydrophilic and hydrophobic moieties, which are essential for the survival of the microorganisms by acting as biocide agents, facilitating microbe-host interactions or facilitating nutrient transporting (Van Hamme et al., 2006; Rashad et al., 2014a). Sophorolipids (SLs) are a sort of extracellular glycolipid biosurfactant and they are produced by yeasts such as Candida bombicola. They consist of one sophorose molecule attached to one hydroxyl fatty acid by one or two cross lines (Price et al., 2012).

Having the ability to emulsifying fats, SLs are expected to exert a role in cholesterol metabolism in humans. Therefore, this study aims to produce low cost SL compounds using C. bombicola cultivated on safflower oil cake (which is an industrial waste) using a solid-state fermentation (SSF) technique. Also, to investigate their possible hypocholesterolemic effects on hypercholesterolemic rats compared to one of the commonly used statin family members; rosuvastatin.

\section{MATERIALS AND METHODS}

\subsection{Materials}

\subsubsection{Substrates}

Safflower seeds (CarthamusTinctoriusL.) namely Giza 1 were obtained from the local market (Cairo, Egypt). The safflower seeds were pressed with laboratory-type Carver hydraulic press under $10.000 \mathrm{Ib}$ in $^{-2}$ pressure for $1 \mathrm{~h}$ at room temperature according to (Üstun et al., 1990), then the safflower oil cake residue was collected, frozen and kept at $-4{ }^{\circ} \mathrm{C}$ until analysis. Crude soybean oil was obtained from the Food Technology Research Institute, Soy Processing Centre, Agriculture Research Centre, (Giza, Egypt).

\subsubsection{Yeast strain}

Candida bombicola NRRL Y-17069 was obtained from the Agricultural Research Service, (Peoria, Illinois, USA). The culture was kept in a stock slant medium (Wickerham, 1951).

\subsubsection{Animal Experiment}

Most of the ingredients used for preparation of the diet (Table 1) that was introduced to the rats were obtained from the local market, while, casein was obtained from Scerma Co., (France). The salt and vitamin mixtures used were of analytical grade and obtained from Fluka (Germany) and BDH (England) Chemical Companies. Cellulose and cholesterol powder were obtained from FineChem Limited (Mumbai, India). The hypocholesterolemic drug (rosuvastatin) was obtained from 
IPR Pharmaceutical Inc., (Egypt) under license of Puerto Rico (AstraZeneca), (UK).

The kits used for the determination of blood hemoglobin $(\mathrm{Hb})$, plasma glucose, plasma catalase, erythrocyte (RBCs) glutathione peroxidase (GPx) and RBCs superoxide dismutase (SOD) were obtained from the Biodiagnostic Company, (Egypt). The kit used for the determination of plasma triacylglycerols (TG) was obtained from the Stanbio Laboratory Company, (USA). The kits used for the estimation of plasma total cholesterol (TC), high density lipoprotein cholesterol (HDL-C), urea, and creatinine were purchased from Chronolab Systems, (Barcelona, Spain). The kits used for the determination of plasma aspartate aminotransferase (AST) and alanine aminotransferase (ALT) were obtained from the Salucea Co., (Netherlands). The chemicals used for the determination of plasma lipid peroxide product (malondialdehyde: MDA); the thiobarbituric acid (TBA) and the trichloroacetic acid (TCA) were obtained from the Merck (Germany) and BDH (England) Companies, respectively.

The animals used in the biological experiment were Sprague Dawley male albino rats. They were obtained from the Central Animal House, National Research Centre, (Egypt). The study protocol was approved by Scientific Committee at the National Research Centre (NRC, Egypt). Animal experiments were conducted according to the guidelines of animal care and ethics committee of the NRC (Approval no: 15118).

\subsection{Methods}

\subsubsection{Inoculum preparation}

The inoculum was prepared by transferring a loop full of a stock culture (7 days old) of

TABle 1. Composition of the diets of control rats $(\mathrm{g} / 100 \mathrm{~g})$ diet

\begin{tabular}{lc}
\hline \multicolumn{1}{c}{ Ingredients } & Amount (g) \\
\hline Casein* & 21.9 \\
Sucrose & 5 \\
Cellulose & 4 \\
Corn oil & 8 \\
Salt mixture (AIN-93 )* & 3.5 \\
Vitamin mixture (AIN-93)* & 1 \\
Choline bitartrate & 0.25 \\
L- Cystine & 0.18 \\
Corn starch & 56.17 \\
\hline
\end{tabular}

*Protein content of casein was estimated as $54.6 \%$. Salt and vitamin mixtures were prepared according to Reeves et al., 1993.
C. bombicola NRRL Y-17069 to a $50 \mathrm{~mL}$ sterile inoculum medium (Wickerham, 1951), which was then incubated at $30^{\circ} \mathrm{C}, 180 \mathrm{rpm}$ for $24 \mathrm{~h}$.

\subsubsection{Cultivation conditions}

The SSF medium was prepared according to the method of Rashad et al. (2014a) with some modifications as follows: $5 \mathrm{~g}$ of safflower oil cake waste, $5 \mathrm{~g}$ of soybean oil and $4 \mathrm{~mL}$ of nutrients solution consisting of $\left(\mathrm{g} \cdot \mathrm{L}^{-1}\right) \mathrm{NH}_{4} \mathrm{NO}_{3}, 1.0$; $\mathrm{K}_{2} \mathrm{HPO}_{4}, 2.55 ; \mathrm{NaH}_{2} \mathrm{PO}_{4}, 0.15 ; \mathrm{MgSO}_{4} .7 \mathrm{H}_{2} \mathrm{O}$, $0.5 ; \mathrm{CaCl}_{2} .2 \mathrm{H}_{2} \mathrm{O}, 0.1 ; \mathrm{MnSO}_{4} \cdot \mathrm{H}_{2} \mathrm{O}, 0.02$; peptone, 1.0. Final $\mathrm{pH}$ was adjusted to 7.8. One $\mathrm{ml}$ of the overnight culture $\left(1 \times 10^{8} \mathrm{cell} \mathrm{ml}^{-1}\right)$ was mixed for seeding thoroughly to the above sterilized media $\left(121{ }^{\circ} \mathrm{C}, 20 \mathrm{~min}\right)$ for 14 days and incubated in static condition at $28-30{ }^{\circ} \mathrm{C}$.

\subsubsection{Extraction of SLS}

\subsubsection{Methanol Extraction}

The crude SLs were isolated according to Rashad et al. (2014a) by adding $45 \mathrm{ml}$ of methanol to one volume of the fermented solid waste and the mixture was shaken at 90 strokes $\mathrm{min}^{-1}$ for $60 \mathrm{~min}$ with a reciprocal shaker (New Brunswick Scientific, USA). The crude extract was then filtered through Whatman no. 40 filter paper to obtain the methanol extract (ME).

\subsubsection{Re-extraction by ethyl acetate}

The re-extraction was made according to Rashad et al. (2014a) by re-extracting the residual fermented substrates with $45 \mathrm{~mL}$ of ethyl acetate and shaking at 90 strokes $\mathrm{min}^{-1}$ for $60 \mathrm{~min}$ with a reciprocal shaker, filtered by Whatman 40 filter paper to obtain the second ethyl acetate extract (EAE).

\subsubsection{Fourier transform infrared spectroscopy (FTIR)}

The infrared (IR) spectrum (from 400 to 4000 wave numbers, $\mathrm{cm}^{-1}$ ) of SLs extracts were recorded using a $\mathrm{KBr}$ pellet in Nicolet Impact 6100 FTIR spectrophotometer JASCO, USA.

\subsection{5. ${ }^{1} H$ NMR spectra analysis}

The NMR spectra were recorded on a Varian Mercury VX-300 NMR spectrometer. ${ }^{1} \mathrm{H}$ spectra were run at $300 \mathrm{MHz}$ in deuterated chloroform $\left(\mathrm{CDCl}_{3}\right)$. Chemical shifts are quoted in $\delta$ and were related to those of the solvents. 


\subsubsection{Biological Evaluation}

\subsubsection{Acute toxicity test}

First, the obtained extracts were subjected to an acute lethal toxicity test $\left(\mathrm{LD}_{50}\right)$ to evaluate their safety. This was done according to Goodman et al., (1980). A number of 84 Swiss male albino mice were included. They were divided into 14 groups of 6 mice each. Two sets of groups were included, seven groups for the methyl extract (ME) and seven groups for the EAE. Then, progressively increasing oral doses from each extract calculated as $\mathrm{g} / \mathrm{Kg} \mathrm{B}$. wt. were given to the groups of each set as follows; $1,2,4,6,8,10,12$. Then, the 24 -hour mortality counts of the animals were observed and recorded.

\subsubsection{Formulation of the diet}

The standard control diet was prepared according to Reeves et al. (1993) as shown in Table 1. The high-cholesterol and high-fat diets was prepared by adding $2 \%$ pure cholesterol, $0.25 \%$ bile salts and $20 \%$ fat to the standard diet at the expense of starch.

This experiment was done on 42 male Sprague dawley albino rats of body weight from 100 to $120 \mathrm{~g}$. Each rat was housed individually in a separate cage in an air conditioned room regulated at a temperature of $25^{\circ} \mathrm{C}$. Food and water were administered to the rats ad-libitum. A group of 7 rats was separated from the whole group to serve as a negative control group (control -ve) and fed the standard control diet (Table 1). The rest of the rats were fed a high-fat and high-cholesterol diet (HFHC) containing $200 \mathrm{~g}$ lard $/ \mathrm{Kg}$ diet, $20 \mathrm{~g}$ cholesterol $/ \mathrm{Kg}$ diet and $0.25 \%$ bile salts for eight weeks to induce hypercholesterolemia (Mahmoud et al., 2011). Then, the hypercholesterolemic rats were divided into 5 groups of 7 rats each as follows:

Group 2: Hypercholesterolemic rats fed the $\mathrm{HFHC}$ diet and given an oral dose of saline to serve as a control positive group (control $+\mathrm{ve}$ ).

Group 3: Hypercholesterolemic rats fed the HFHC diet and given a daily oral dose of rosuvastatin (Ros.) $10 \mathrm{mg} / \mathrm{kg}$ body weight (HFHC+Ros).

Group4: Hypercholesterolemic rats fed the HFHC diet and given a daily oral dose of the methyl extract (ME) as $200 \mathrm{mg} / \mathrm{kg}$ body weight (HFHC+ME).

Group5: Hypercholesterolemic rats fed the HFHC diet and given a daily oral dose of the EAEas $200 \mathrm{mg} / \mathrm{Kg}$ body weight (HFHC+EAE).

Group 6: Hypercholesterolemic rats fed the HFHC diet and given a daily oral dose of a mixture (Mix.) of ME and EAE (1:1) as $200 \mathrm{mg} / \mathrm{Kg}$ body weight (HFHC + Mix).
Body weight and daily food consumption were followed and recorded. After four weeks, fasting blood samples were obtained from the suborbital vein under slight diethyl ether anesthesia, separated and stored at $-70{ }^{\circ} \mathrm{C}$ until analysis. The organs including liver, heart, kidneys and brain were separated, weighed and a portion of each organ was embedded into $10 \%$ formalin solution for histopathological examination.

\subsubsection{Biochemical analysis}

Blood hemoglobin was determined according to Betke and Savelsberg (1950). The antioxidant enzymes namely RBCs SOD, plasma catalase and RBCs GPx were estimated according to the methods of Nishikimi et al. (1972), Aebi (1984) and Paglia and Valentine (1967), respectively. Plasma peroxidation product; MDA was detected by the thiobarbituric acid (TBA) assay according to the method of Draper and Hadley (1990). Blood glucose was estimated according to the method described by Trinder (1969). The activities of both ALT \& AST were measured according to the method of Henry et al. (1960). Plasma urea and creatinine were assessed as described by Fawcett and Scott (1960) and Murray (1984), respectively.

Lipid parameters were estimated as follows; plasma triacylglycerols was assessed as described by Scheletter and Nussel (1975). Plasma total cholesterol was determined as described by Meiattini et al. (1978). HDL-C was determined according to Grove (1979). Low-density lipoprotein cholesterol (LDL-C) and very-low-density lipoprotein cholesterol (VLDL-C) were determined according to Warnick et al. (1990) as shown in the following equations:

\section{LDL-C $=$ Total cholesterol $-($ HDL-C + VLDL-C $)$}

Where, VLDL-C $=$ Triacylglycerols $/ 5$

Atherogenic index (A.I.) was calculated as described by Dobiasova (2004) according to the equation:

A.I. $=\log$ (triacylglycerols/ HDL-C).

The concentration of all of the previously mentioned biochemical parameters were measured by a colorimetric technique using a spectrophotometer (Shimadzu UV-2401 PC, Australia).

\subsubsection{Histopathological analysis}

Specimens from liver, heart, kidney and brain were histopathologically examined after being cleared in xylol, embedded in paraffin, sectioned at 4-6 micron thickness and stained with Heamatoxylin and Eosin. Finally, they were examined under microscope. 


\subsubsection{Statistical analysis}

Results were analyzed statistically using the computerized program SPSS version " 20 ". The one way ANOVA test was done followed by the Duncan test. Data were represented as mean \pm SE. Significance was considered at a level of 0.05 .

\section{RESULTS AND DISCUSSION}

Controlling blood cholesterol is important for reducing the risk of developing atherosclerosis (Jegadeesh et al., 2014). In fact, although the current hypocholesterolemic drugs such as statins give good results for lowering cholesterol with well-known mechanisms (Rideout et al., 2010), the need for alternative drugs is pivotal due to some disadvantages of the current drugs among which is the lack of positive effect on HDL-C (Kobayashi et al., 2008). Also, many side effects from the use of statins were detected (Graveline, 2015) as well as the high cost for the production of these synthetic drugs. Consequently, searching for natural products with few or no side effects and lower cost becomes necessary. SLs as a type of bio-surfactants are known to have medical application for their health benefits (Price et al, 2012). One of the objectives in this study was to find a suitable economic substrate for the production of SLs and to examine their ability to lower cholesterol in the hypercholesterolemic rats. The SSF technique was employed with a mixture of safflower oil cake and crude soybean oil. Extraction of the crude SLs was carried out using methanol as the first extraction solvent, which resulted in a yield of $24.4 \mathrm{~g} \cdot 100 \mathrm{~g}^{-1}$ mixed substrate, while the re-extraction by ethyl acetate from the remaining culture gave a higher yield of SLs $\left(48.3 \mathrm{~g} \cdot 100 \mathrm{~g}^{-9}\right.$ mixed substrate).

Safflower oil cake and soybean oil mixture with the SSF technique was used for the first time in the production of SLs. Previously, safflower oil was added as a source of fatty acids with the liquid fermentation technique for the production of SLs by Torulopsis bombicola (Ito and Inoue, 1982). Rahman et al. (2002) also used safflower oil and soybean oil for the production of rhamnolipid bio-surfactant from Pseudomonas aeruginosa GS9119 and DS10-129 using the liquid fermentation technique.

Regarding the production process, the yield of SLs resulting in this study from the extraction and reextraction technique was higher than that obtained from previous works $\left(17 \mathrm{~g} \cdot 100 \mathrm{~g}^{-1}\right.$ and $\left.32.5 \mathrm{~g} \cdot 100 \mathrm{~g}^{-1}\right)$ and $\left(4.75 \mathrm{~g} \cdot 100 \mathrm{~g}^{-1}\right.$ and $\left.41.77 \mathrm{~g} \cdot 100 \mathrm{~g}^{-1}\right)$ for the production of SLs using sunflower oil cake plus soybean oil or motor oil waste respectively, fermented by $C$. bombicola ( Rashad et al, $2014 \mathrm{a}$ and b). Lower yield was also reported $\left(23.5 \mathrm{~g} \cdot 100 \mathrm{~g}^{-1}\right.$ dry matter) for the production of SLs using the SSF of sunflower winterization oil cake plus sugar beet molasses by Starmerella bombicola ATCC 22214 (Jiménez-Peñalver et al., 2016). The yield obtained in this study was also higher than that produced by Parekh and Pandit (2012), who found that the SSF of glucose, wheat bran and oleic acid by Starmerella bombicola NRRL Y-17069 produce a maximum SL yield of $18 \mathrm{~g}$ per $100 \mathrm{~g}$ substrate.

The isolated SL compounds (M \& EA extracts) were identified and characterized by FTIR (Figure 1). The obtained data revealed the presence of broad bands at 3387 and $3471 \mathrm{~cm}^{-1}$ corresponding to the $\mathrm{O}-\mathrm{H}$ stretch in $\mathrm{ME} \& \mathrm{EAE}$ extracts structure, respectively. Asymmetrical stretching $\left(\mathrm{v}_{\mathrm{as}} \mathrm{CH}_{2}\right)$ and symmetrical stretching $\left(\mathrm{v}_{\mathrm{s}} \mathrm{CH}_{2}\right)$ of methylene groups were observed in 2925 and 2857 in both extracts, respectively. Absorption bands at $\left(1743-1746 \mathrm{~cm}^{-1}\right)$ were contributed to $\mathrm{C}=\mathrm{O}$ stretching from lactone ester or acids in both structures. The bands at 1459 and $1457 \mathrm{~cm}^{-1}$ corresponded to the $\mathrm{C}-\mathrm{O}-\mathrm{H}$ in plane binding of carboxylic acid (-COOH) in the structure of $\mathrm{M} \& \mathrm{EA}$ extracts, respectively. The $\mathrm{C}=\mathrm{O}$ absorption band from acetyl esters was observed at $1235 \mathrm{~cm}^{-1}$ in both extracts, while the stretch of the $\mathrm{C}-\mathrm{O}$ band of $\mathrm{C}(-\mathrm{O})-\mathrm{OC}$ in lactones exists at 1166 and $1163 \mathrm{~cm}^{-1}$ in $\mathrm{M}$ and EA fractions, respectively. However, the $\mathrm{C}-\mathrm{O}$ stretch of $\mathrm{C}-\mathrm{O}-\mathrm{H}$ groups of sophorose moiety was observed at 1047 and $1026 \mathrm{~cm}^{-1}$ in both extracts, respectively. The IR spectra also revealed the absorption bands at $722-721 \mathrm{~cm}^{-1}$ for $\mathrm{C}=\mathrm{C}$ in both $\mathrm{M}$ and $\mathrm{EA}$ extracts, respectively.

The structure of the produced SL compounds (M and EA extracts) was assigned to a typical glyco-lipid-type structure using ${ }^{1} \mathrm{H}$ NMR spectrum analysis. A resonance of two protons for glucose molecules was detected in both extracts between 3.42 to $4.26 \mathrm{ppm}$. The existence of a fatty acid chain was confirmed by the multiple signals between 1.22 and $1.27 \mathrm{ppm}$, while the signals from 5.3 to 5.34 gave the evidence for the existence of a vinyl group $(-\mathrm{CH}=\mathrm{CH}-)$ in both extracts.

The structural characterization of the produced SL extracts was confirmed by the FT-IR and 1H NMR analyses which was in agreement with Rashad et al, (2014 a and b) and Jiménez-Peñalver et al. (2016). According to the results of the FT-IR and ${ }^{1}$ HNMR analyses, all these structural features further confirmed the existence of SL groups in the isolated compounds (acidic and lactone ring form).

The presence of unsaturated fatty acids in the SL structure which was proven by the structural characterization using FTIR and H1 NMR could play a role in decreasing plasma cholesterol 

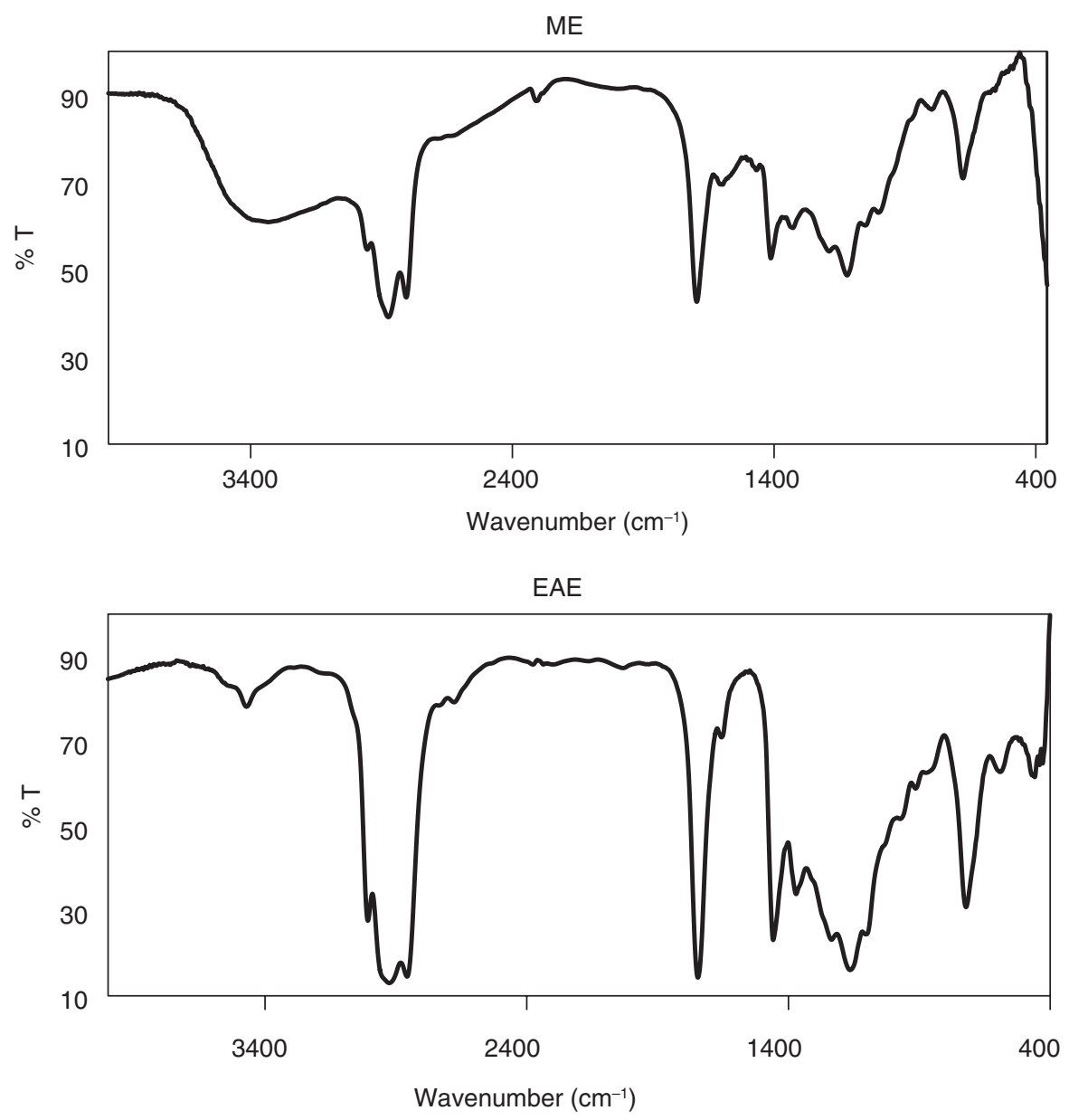

FIGURE 1. FTIR spectra of the isolated sophorolipids compounds (ME \& EAE).

concentrations. Kris-Etherton and $\mathrm{Yu}$ (1997) stated that plasma cholesterol concentrations were decreased by mono and poly-unsaturated fatty acids in clinical experiments. Also Fernandez and West (2005) reported that the poly-unsaturated fatty acids increase the hepatic LDL-C receptor number, LDL-C turnover in vivo and modulate VLDL-C metabolism resulting in the reduction of the plasma triglycerides level. Thus, with its unsaturated fatty acid content and for being a member of the bio-surfactant family which is known to have surface and emulsifying activities, SLs were expected to have hypocholesterolemic effects. Therefore, this study was directed at evaluating the effect of these compounds on lipid metabolism in hypercholeterolemic rats.

In the present study, the obtained SL compounds, in either of the ME or the EAE were proven to be safe and have no acute toxicity effect, as evidenced from the data of the $\mathrm{LD}_{50}$ experiment, since no mortality was noticed for any of the tested doses up to $12 \mathrm{~g} \cdot \mathrm{Kg}^{-1}$ mice body weight.
Although the results obtained from this study illustrated that some variations occurred in the body weight either increased or decreased change compared to the negative control negative group, none of these changes were significant (Table 2). However, there was a significant reduction in food intake in the positive control group compared to the negative control group. The non-significant reduction in the body weight gain reported for the control positive group was in contrast to the results obtained by Samarghandian et al. (2011). On the other hand, Mohamed et al. (2005) concluded from their experiment that non-significant changes were observed in body weight gain, while the total food intake and food intake/day were significantly lower in hypercholesterolemic rats compared to the normal rats and these results seems to be in accordance with our results for both body weight gain and food intake. Also, Cha et al. (2016) reported similar results for the decreased food intake of the positive control group. The decrease in body weight may be attributed to the reduction in food intake for the 
Hypocholesterolemic impact of newly isolated sophorolipids produced by microbial conversion of safflower oil cake $\bullet 7$

TABLE 2. Body weight gain, food intake and feed efficiency ratio (FER) of the control group and the different groups

\begin{tabular}{lclc}
\hline Group & Body Weight Gain (g) & Food intake (g) & FER* $^{*}$ \\
\hline Control (-ve) & $30.17 \pm 1.99^{\mathrm{ab}}$ & $423.33 \pm 6.78^{\mathrm{a}}$ & $0.071 \pm 0.005^{\mathrm{a}}$ \\
Control (+ve) & $18.00 \pm 1.86^{\mathrm{a}}$ & $329.33 \pm 13.73^{\mathrm{b}}$ & $0.057 \pm 0.006^{\mathrm{a}}$ \\
HFHC + Ros & $30.00 \pm 4.28^{\mathrm{ab}}$ & $419.00 \pm 9.18^{\mathrm{a}}$ & $0.077 \pm 0.011^{\mathrm{a}}$ \\
HFHC + ME & $42.14 \pm 8.56^{\mathrm{b}}$ & $418.57 \pm 4.27^{\mathrm{a}}$ & $0.069 \pm 0.017^{\mathrm{a}}$ \\
HFHC + EAE & $32.00 \pm 4.42^{\mathrm{ab}}$ & $418.57 \pm 12.23^{\mathrm{a}}$ & $0.076 \pm 0.011^{\mathrm{a}}$ \\
HFHC + Mix & $22.29 \pm 2.46^{\mathrm{a}}$ & $340.14 \pm 10.45^{\mathrm{b}}$ & $0.063 \pm 0.009^{\mathrm{a}}$ \\
\hline
\end{tabular}

*FER is calculated as body weight gain / food intake. Values are expressed as mean \pm SE and the mean difference is significant at $\mathrm{P}<0.05$. Values that share the same letter $(\mathrm{a}, \mathrm{b}$ or $\mathrm{c})$ in the same column are not significant while, values that share different letters in the same column are significant.

TABLE 3. Organ weight percent $\%$ of the control group and other groups

\begin{tabular}{|c|c|c|c|}
\hline Group & Heart wt. \% & Liver wt. $\%$ & Kidney wt. \% \\
\hline Control (-ve) & $0.42 \pm 0.05^{\mathrm{a}}$ & $3.17 \pm 0.10^{\mathrm{a}}$ & $0.63 \pm 0.02^{\mathrm{a}}$ \\
\hline Control (+ve) & $0.40 \pm 0.03^{\mathrm{a}}$ & $4.62 \pm 0.18^{\mathrm{b}}$ & $0.73 \pm 0.03^{\mathrm{b}}$ \\
\hline $\mathrm{HFHC}+\mathrm{Ros}$ & $0.43 \pm 0.02^{\mathrm{a}}$ & $4.28 \pm 0.12^{\mathrm{b}}$ & $0.67 \pm 0.02^{\mathrm{ab}}$ \\
\hline $\mathrm{HFHC}+\mathrm{ME}$ & $0.43 \pm 0.02^{\mathrm{a}}$ & $4.60 \pm 0.15^{\mathrm{b}}$ & $0.67 \pm 0.03^{\mathrm{ab}}$ \\
\hline $\mathrm{HFHC}+\mathrm{EAE}$ & $0.45 \pm 0.02^{\mathrm{a}}$ & $4.75 \pm 0.16^{\mathrm{b}}$ & $0.60 \pm 0.03^{\mathrm{a}}$ \\
\hline HFHC + Mix & $0.42 \pm 0.02^{\mathrm{a}}$ & $4.45 \pm 0.36^{\mathrm{b}}$ & $0.65 \pm 0.03^{\mathrm{ab}}$ \\
\hline
\end{tabular}

*Values are expressed as mean $\pm \mathrm{SE}$ and the mean difference is significant at $\mathrm{P}<0.05$. Values that share the same letter $(\mathrm{a}, \mathrm{b}$ or $\mathrm{c})$ in the same column are not significant while, values that share different letters in the same column are significant.

positive control group when compared to the negative control group. Anyhow, the reduction in both food intake and body weight gain returned back to the normal values of the negative control group in the case of the HFHC groups that received either rosuvastatin or EAE. While in case of ME, the body weight gain was not only returned to the value of the negative control group but, it exceeded this value. However, the HFHC group that received the mixture of the two extracts showed a slight improvement which was non-significant. The improvement in the HFHC group that received EAE is considered as a good mark for the positive effect of this extract.

An increase in the liver weight \% (hepatosomatic index) in all groups that received $\mathrm{HFHC}$ was noticed which reached up to $49 \%$ compared to the negative control group (Table 3). This increase can be attributed to the accumulation of fat, particularly the triacylglycerols, in liver tissue as reported by Fassini et al. (2011). As expected, it is obvious that no improvement occurred for the hepatosomatic index for any of the HFHC groups that received any of the treatments (rosuvastatin or the extracts). Although all the treatments used either rosuvastatin or the extracts had a highly positive effect on plasma lipid profile, the liver weight did not return back to its normal weight, i. e. there was still an accumulation of fat in the liver with the same proportion which may be explained on the basis that the liver triacylglycerols needed more time to be removed from the liver tissue than did those of the plasma. This explanation seems to be in accordance with the findings of Fassini et al. (2011) who reported that the reduction in liver triacylglycerols of hypercholesterolemic rats that received either rosuvastatin or soybean glycinin was slight (still about 3 times as high as that of the negative control value) although the reduction in plasma triacylglycerols was pronounced. Thus, the liver tissue requires more time to be recovered. This result was reinforced by the histopathological examination (as will be shown later) which revealed that there was still steatosis in the liver of the HFHC groups that received any of the treatments just as the negative control group and no detectable improvement was recorded indicating that the liver needed more time to return back to its normal state. Also, a significant increase in the kidney weight $\%$ was observed for the positive control group compared to the negative control. However, this increase returned back to more or less the normal value of the control negative group in the case of the groups that received any of the treatments. This improvement was nonsignificant compared to the negative control group in all treated groups meaning that their values became close to that of the negative control group which is a good sign and the best result was that recorded for the EAE, since it became significantly different from the positive control group.

No significant changes were reported for the hemoglobin concentration which reflected the safety 
of the extracts on hemoglobin synthesis (Table 4). Glucose concentration was neither altered in the positive control group compared to the negative control nor changed in any of the HFHC groups that were given the extracts or rosuvastatin. The nonsignificant change in the glucose level in the positive control group was also reported by Cha et al. (2016). Moreover, a non-significant change was detected for both urea and creatinine in all examined groups, which reflected the safety of these extracts as well as rosuvastatin on the renal tissue.

The liver function represented by the two enzymes namely, ALT and AST was affected by the induction of hypercholesterolemia (Table 4). An increase in both ALT and AST was observed in the positive control group $(39.83 \pm 2.18 \mathrm{U} / \mathrm{L}$ and 56.00 $\pm 7.50 \mathrm{U} / \mathrm{L}$, respectively) compared to the negative control $(30.33 \pm 2.39 \mathrm{U} / \mathrm{L}$ and $32.17 \pm 3.17 \mathrm{U} / \mathrm{L}$ for ALT and AST, respectively). Abreu et al. (2014) reported similar results of increased ALT and AST in hypercholesterolemic rats. This increase in the present study was significant only in the case of AST reaching about twice the value for the negative control group. The increase in liver enzymes of the positive control group may be attributed to the disturbances that occurred in the liver tissue due to the accumulation of fat in hepatocytes which led to injured hepatocytes, thus affecting their cell membrane permeability and leakage of the hepatic enzymes into blood circulation. Bose et al. (2008) reported that feeding mice a high-fat diet revealed an increase in liver enzymes which is due to the high-fat-induced hepatocyte injury. Also, according to Pincus and Schaffner (1996), AST and ALT are released markedly into serum as a result of severe hepato-cellular injury. Ferreira et al. (2015) reported similar results for the ALT activity in the hypercholesterolemic rats. The increase in the ALT activity continued and became significant in case of the HFHC group which was treated with rosuvastatin $(48.00 \pm 2.11 \mathrm{U} / \mathrm{L})$ compared to the negative control group $(30.33 \pm 2.39 \mathrm{U} / \mathrm{L})$ indicating a negative effect of rosuvastatin on the liver. This had been reported previously by Calderon et al. (2010), who stated that the most commonly reported adverse effect for statins on the liver is the phenomenon known as transaminitis, in which liver enzyme levels are elevated in the absence of any proven hepatotoxicity. This condition of elevated liver enzymes due to the use of statins requires discontinuation of treatment, leaving a large number of at-risk patients untreated. On the other hand, using any of the extracts (either the methanol or the ethyl acetate or the mixture of both of them) did not cause any further increase in the activity of ALT and AST compared to the positive control group. It is worth mentioning that the EAE showed a reduction in the ALT activity $(30.67 \pm 4.70 \mathrm{U} / \mathrm{L})$ so that it returned back to the normal level of the negative control $(30.33 \pm 2.39 \mathrm{U} / \mathrm{L})$, reflecting the ability of this extract to counteract the negative effect of the high-fat diet on the liver tissue and hence decrease the high-fat-induced hepatocyte injury. In respect to the activity of AST, the significant increase in the positive control group may be explained by the fact that this enzyme is not only indicative for liver tissue, but also it may be elevated in diseases in other organs such as the heart, pancreas, kidney, red blood cells, brain and skeletal muscles (Nissen et al., 1965). In this study, hypercholesterolemia, with its consequent increased oxidative stress, affects many of these organs as evidenced by the histopathology of liver, kidney, heart and brain which will be described later. Consequently, AST activity was expected to be markedly elevated due to all these involved organs, but, this increase was reduced when using either rosuvastatin or any of the other extracts, reflecting their ability to ameliorate the negative effect of the high-fat diet on different organs.

A key point in the present study is that the isolated SLs were not only able to reduce plasma cholesterol in the HFHC fed rats as efficiently as rosuvastatin, but were also able to increase the HDL-C fraction (the good cholesterol) of these rats while the rosuvastatin was not able to do that (Table 5). Also, the isolated

TABLE 4. Concentration of hemoglobin and plasma glucose, activities of plasma ALT and AST and concentration of urea and creatinine in all groups

\begin{tabular}{lcccccc}
\hline Group & $\begin{array}{c}\text { Hb } \\
(\mathbf{g} / \mathbf{1 0 0} \mathbf{~ m L})\end{array}$ & $\begin{array}{c}\text { Glucose } \\
(\mathbf{m g} / \mathbf{1 0 0} \mathbf{~ m L})\end{array}$ & $\begin{array}{c}\text { ALT } \\
(\mathbf{U} / \mathbf{L})\end{array}$ & $\begin{array}{c}\text { AST } \\
(\mathbf{U} / \mathbf{L})\end{array}$ & $\begin{array}{c}\text { Urea } \\
(\mathbf{m g} / \mathbf{1 0 0} \mathbf{~ m L})\end{array}$ & $\begin{array}{c}\text { Creatinine } \\
(\mathbf{m g} / \mathbf{1 0 0} \mathbf{~ m L})\end{array}$ \\
\hline Control (-ve) & $14.55 \pm 0.49^{\mathrm{a}}$ & $96.07 \pm 2.64^{\mathrm{a}}$ & $30.33 \pm 2.39^{\mathrm{a}}$ & $32.17 \pm 3.17^{\mathrm{a}}$ & $31.90 \pm 1.56^{\mathrm{a}}$ & $0.62 \pm 0.10^{\mathrm{a}}$ \\
Control (+ve) & $14.80 \pm 0.25^{\mathrm{a}}$ & $93.48 \pm 7.97^{\mathrm{a}}$ & $39.83 \pm 2.18^{\mathrm{ab}}$ & $56.00 \pm 7.50^{\mathrm{b}}$ & $36.45 \pm 5.37^{\mathrm{a}}$ & $0.51 \pm 0.08^{\mathrm{a}}$ \\
HFHC + Ros & $14.03 \pm 0.40^{\mathrm{a}}$ & $90.39 \pm 5.34^{\mathrm{a}}$ & $48.00 \pm 2.11^{\mathrm{b}}$ & $43.50 \pm 6.40^{\mathrm{ab}}$ & $28.87 \pm 2.90^{\mathrm{a}}$ & $0.48 \pm 0.10^{\mathrm{a}}$ \\
HFHC + ME & $13.77 \pm 0.32^{\mathrm{a}}$ & $89.21 \pm 4.67^{\mathrm{a}}$ & $42.00 \pm 4.83^{\mathrm{ab}}$ & $41.00 \pm 4.89^{\mathrm{ab}}$ & $31.87 \pm 3.45^{\mathrm{a}}$ & $0.52 \pm 0.09^{\mathrm{a}}$ \\
HFHC + EAE & $13.75 \pm 0.72^{\mathrm{a}}$ & $100.7 \pm 8.31^{\mathrm{a}}$ & $30.67 \pm 4.70^{\mathrm{a}}$ & $48.33 \pm 2.45^{\mathrm{ab}}$ & $35.12 \pm 1.90^{\mathrm{a}}$ & $0.72 \pm 0.05^{\mathrm{a}}$ \\
HFHC + Mix & $14.82 \pm 0.52^{\mathrm{a}}$ & $86.10 \pm 3.34^{\mathrm{a}}$ & $41.00 \pm 5.11^{\mathrm{ab}}$ & $44.33 \pm 5.31^{\mathrm{ab}}$ & $31.47 \pm 1.61^{\mathrm{a}}$ & $0.66 \pm 0.07^{\mathrm{a}}$ \\
\hline
\end{tabular}

*Values are expressed as mean $\pm \mathrm{SE}$ and the mean difference is significant at $\mathrm{P}<0.05$. Values that share the same letter $(\mathrm{a}, \mathrm{b}$ or $\mathrm{c})$ in the same column are not significant while, values that share different letters in the same column are significant. 
Hypocholesterolemic impact of newly isolated sophorolipids produced by microbial conversion of safflower oil cake 9

TABLE 5. Concentration of plasma total cholesterol (TC), triglycerides (TG), HDL-C, LDL-C, VLDL-C and atherogenic index (A. I.; $\log$ TG/HDL-C) of the control group and all other groups

\begin{tabular}{lcccccc}
\hline Group & $\begin{array}{c}\text { TC } \\
(\mathbf{m g} / \mathbf{1 0 0} \mathbf{~ m L})\end{array}$ & $\begin{array}{c}\text { TG } \\
(\mathbf{m g} / \mathbf{1 0 0} \mathbf{~ m L})\end{array}$ & $\begin{array}{c}\text { HDL-C } \\
(\mathbf{m g} / \mathbf{1 0 0} \mathbf{~ m L})\end{array}$ & $\begin{array}{c}\text { LDL-C } \\
(\mathbf{m g} / \mathbf{1 0 0} \mathbf{~ m L})\end{array}$ & $\begin{array}{c}\text { VLDL-C } \\
(\mathbf{m g} / \mathbf{1 0 0} \mathbf{~ m L})\end{array}$ & A.I \\
\hline Control (-ve) & $92.10 \pm 10.64^{\mathrm{a}}$ & $74.22 \pm 6.13^{\mathrm{ab}}$ & $45.74 \pm 0.95^{\mathrm{a}}$ & $37.86 \pm 7.44^{\mathrm{a}}$ & $15.84 \pm 0.75^{\mathrm{a}}$ & $0.20 \pm 0.04^{\mathrm{a}}$ \\
Control (+ve) & $260.43 \pm 31.59^{\mathrm{c}}$ & $88.96 \pm 3.75^{\mathrm{b}}$ & $22.26 \pm 2.37^{\mathrm{b}}$ & $215.49 \pm 32.7^{\mathrm{c}}$ & $17.79 \pm 0.75^{\mathrm{ab}}$ & $0.60 \pm 0.05^{\mathrm{b}}$ \\
HFHC+Ros & $126.15 \pm 8.18^{\mathrm{ab}}$ & $77.68 \pm 5.57^{\mathrm{ab}}$ & $21.45 \pm 0.92^{\mathrm{b}}$ & $89.17 \pm 8.63^{\mathrm{b}}$ & $15.54 \pm 1.11^{\mathrm{abd}}$ & $0.55 \pm 0.05^{\mathrm{b}}$ \\
HFHC+ME & $118.47 \pm 9.75^{\mathrm{ab}}$ & $64.36 \pm 9.08^{\mathrm{a}}$ & $41.35 \pm 1.8^{\mathrm{ac}}$ & $65.95 \pm 10.86^{\mathrm{ab}}$ & $11.14 \pm 0.67^{\text {cd }}$ & $0.21 \pm 0.07^{\mathrm{a}}$ \\
HFHC+EAE & $107.46 \pm 11.0^{\mathrm{ab}}$ & $64.60 \pm 5.06^{\mathrm{a}}$ & $31.99 \pm 2.31^{\mathrm{d}}$ & $61.92 \pm 11.57^{\mathrm{ab}}$ & $13.55 \pm 0.94^{\mathrm{cd}}$ & $0.32 \pm 0.03^{\mathrm{a}}$ \\
HFHC+Mix & $151.99 \pm 11.25^{\mathrm{b}}$ & $61.06 \pm 5.69^{\mathrm{a}}$ & $38.53 \pm 2.40^{\mathrm{c}}$ & $101.25 \pm 10.9^{\mathrm{b}}$ & $13.05 \pm 0.80^{\text {cd }}$ & $0.20 \pm 0.05^{\mathrm{a}}$ \\
\hline
\end{tabular}

*Values are expressed as mean $\pm \mathrm{SE}$ and the mean difference is significant at $\mathrm{P}<0.05$. Values that share the same letter $(\mathrm{a}, \mathrm{b}$, $\mathrm{c}$ or $\mathrm{d})$ in the same column are not significant while, values that share different letters in the same column are significant.

SLs lowered the increased LDL-C as shown in Table 5. Furthermore, the SL extracts reduced the levels of triacylglycerols in the HFHC fed rats more efficiently than rosuvastatin. These differences between rosuvastatin and the isolated SLs may be attributed to the different mechanisms for their hypocholesterolemic action. Rosuvastatin is known to reduce serum cholesterol through the inhibition of the very beginning enzyme of the mevalonate pathway; the enzyme 3-hydroxy-3-methylglutaryl-CoA reductase (HMGCoA), which represents the key enzyme in cholesterol biosynthesis (Rideout et al., 2010). The isolated compounds in the present study may accelerate the fecal excretion of bile acids which increase the demand for the synthesis of new bile acids from cholesterol, thus decreasing cholesterol levels in the circulation. Kuwabara et al. (2007), mentioned that cholesterol conversion to bile acids is the major pathway for the elimination of cholesterol and represents about 50\% of daily excretion of cholesterol. Also, the isolated SLs may lower the intestinal absorption of cholesterol by disturbing the micelle formation which is considered one of the mechanisms reported for cholesterol homeostasis in the body (Srinivasan and Sambaiah, 1990). The mechanism of action of these isolated SLs needs more clarification by further investigation. It is worth mentioning that the A.I., which reflects the risk for coronary heart disease, was improved in all groups that received any of the extracts of the isolated SL compounds more efficiently than the rosuvastatin and it returned near the normal values of the negative control group. On the other hand, the value obtained for the rosuvastatin group recorded a slight improvement but still represented a significant increase compared to the negative control group. Based on data from the meta-analysis, a $1 \%$ decrease in serum cholesterol levels can lower the risk of coronary heart disease by up to $3 \%$ and a $10 \%$ reduction in serum cholesterol means a $15 \%$ reduction in risk of mortality from coronary heart disease (Graveline, 2015).

From the present study it can be noticed that hypercholesterolemia caused a state of increased oxidative stress evidenced by the significant increase in the lipid peroxide product in the positive control group (Figure 2-A), with a value of $2.53 \pm 0.25 \mu \mathrm{mol} / \mathrm{mL}$ compared to a value for the negative control group of $1.69 \pm 0.02 \mu \mathrm{mol} / \mathrm{mL}$. This increase was counteracted in all the HFHC groups that received either rosuvastatin $(1.57 \pm$ $0.12 \mu \mathrm{mol} / \mathrm{mL})$ or the extracts $(1.78 \pm 0.09,1.81 \pm$ 0.12 and $1.83 \pm 0.08 \mu \mathrm{mol} / \mathrm{mL}$ for ME, EAE and Mix groups, respectively) indicating that these treatments possess some sort of antioxidant properties. In fact, the increased MDA in the hypercholesterolemic rats was reported before by Anila and Vijayalakshmi (2003). This can be explained by the impact of the high-fat and high-cholesterol diet which induce reactive oxygen species (ROS) overproduction which in turn initiates lipid peroxidation as reported by Montilla et al. (2004). Also, Oyedemi et al. (2010) reported that HFHC diet exerts cytotoxic effects by causing lipid peroxidation resulting in the formation of MDA. In a trail to counteract the increased oxidative stress that was induced by hypercholesterolemia, the body's own antioxidant defense system, the antioxidant enzymes namely; catalase, GPX and SOD began to quench these increased free radicals (Figure 2-B, $2-\mathrm{C}$ and $2-\mathrm{D}$, respectively). Then, the excessive utilization of these enzymes in deactivating the free radicals generated by the HFHC diet (Jiangwei et al., 2011), resulted in a reduction in the activity of the aforementioned antioxidant enzymes in the positive control group. A similar result was reported before by Kassem et al. (2011) who mentioned that antioxidant enzymes were reduced in rats that were fed high-fat and high-cholesterol diets. Introducing either rosuvastatin or any of the extracts restored these enzymes. This ameliorative effect may be attributed to the antioxidant power possessed by the aforementioned treatments which in turn counteracts the overproduction of the increased ROS, thus decreasing the lipid peroxidation and in turn normalizing the antioxidant enzymes.

The results of the histopathological examinations of different organs (Figures 3-6) such as the liver, the 

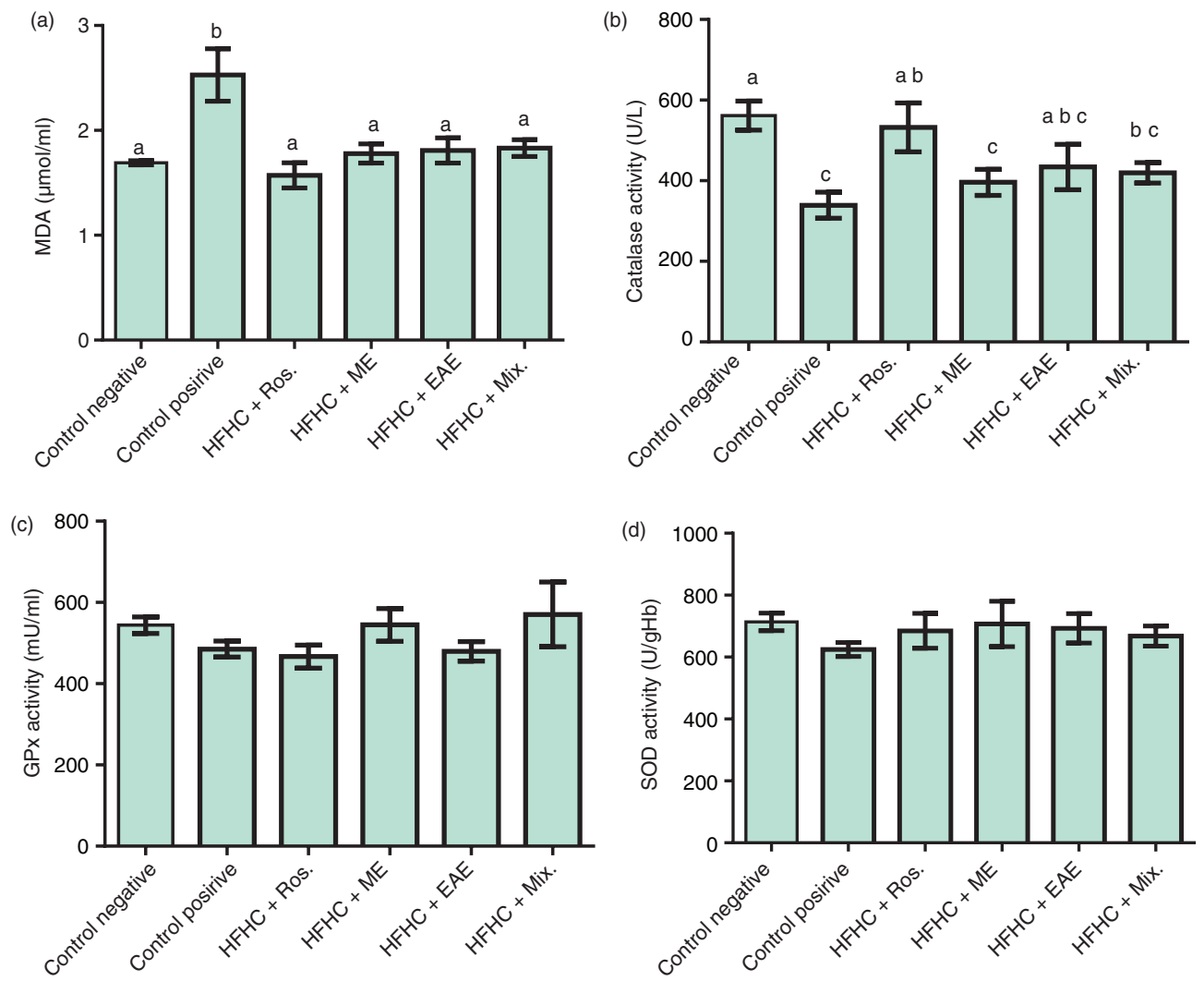

FIgURE 2. A- Concentration of lipid peroxide product; MDA. B- Activity of plasma catalase. C- Activity of RBCs superoxide dismutase (SOD). D- Activity of RBCs glutathione peroxidase (GPx) in all groups

(a)

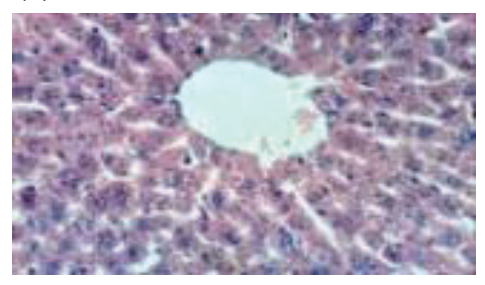

(d)

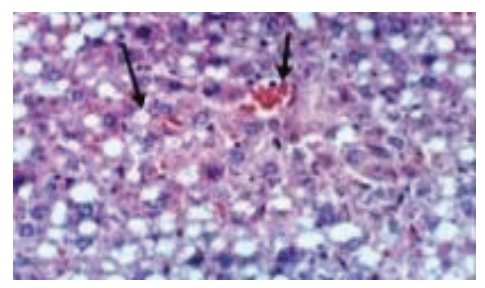

(b)

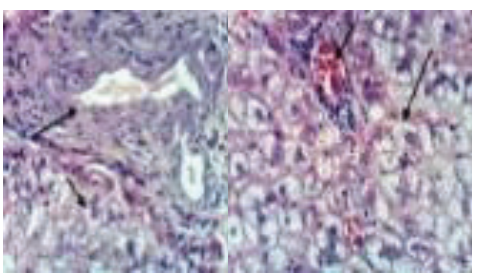

(e)

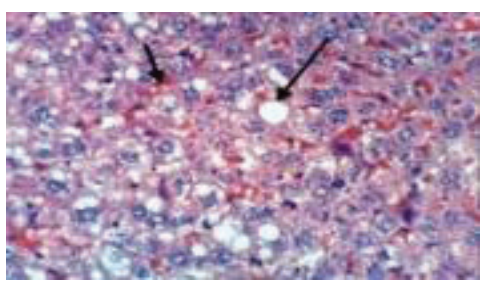

(c)

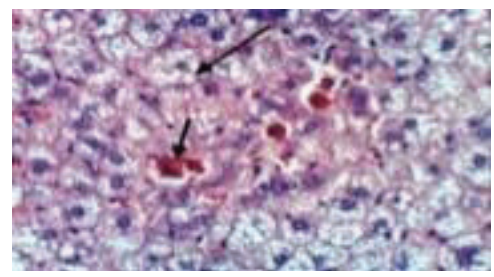

(f)

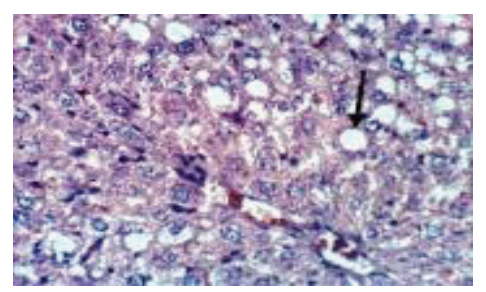

FIGURE 3. Light photomicrographs of livers in rats (a-f). (a) Livers of rats from the negative control group showing the normal histological structure of hepatic lobule. (b) Livers of rats from the positive control group showing the hyperplasia of the biliary epithelium with fibroplasia in the portal triad, steatosis of hepatocytes and congestion of hepatoportal blood vessels. (c) Livers of rats from the hypercholesterolemic group which was given the rosuvastatin showing congestion of the central vein and steatosis of hepatocytes. (d) Livers of rats from the hypercholesterolemic group which was given ME showing the steatosis of hepatocytes and congestion of the central vein. (e) Livers of rats from the hypercholesterolemic group which was given EAE showing the congestion of hepatic sinusoids and the steatosis of hepatocytes. (f) Livers of rats from the hypercholesterolemic group which was given the mixture of both methanol and EAE showing the fatty change of focal hepatocytes (H \& E X 400). 
(a)

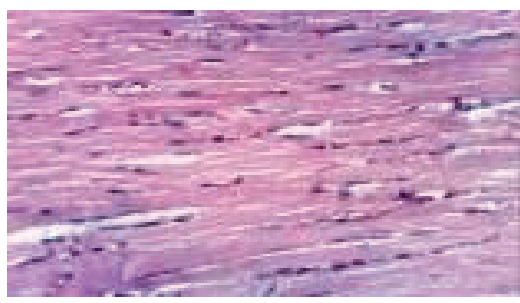

(d)

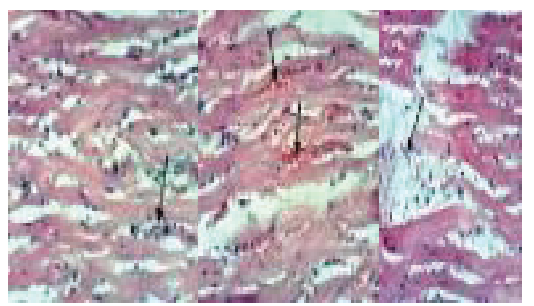

(b)

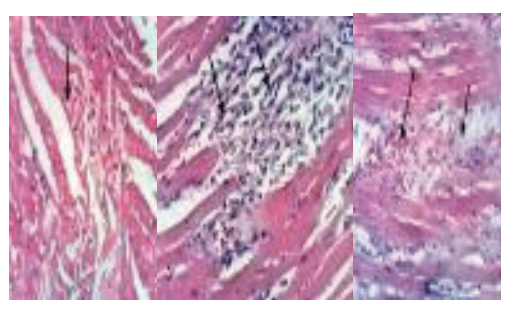

(e)

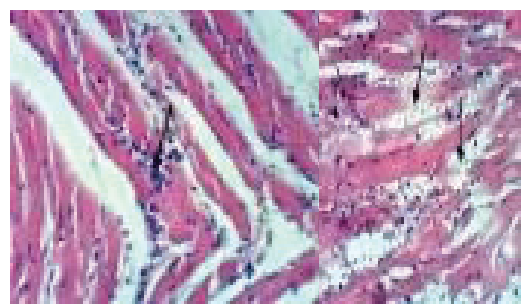

(c)

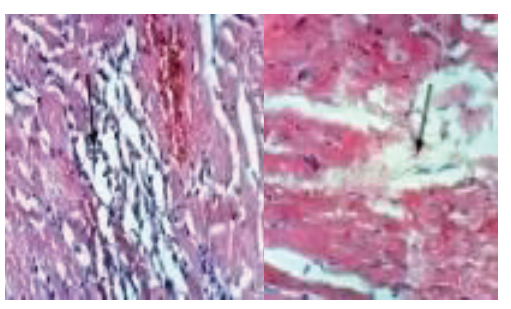

(f)

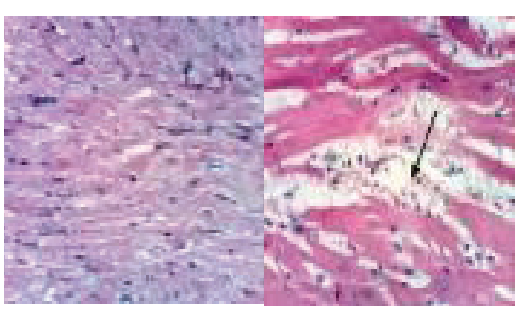

FIGURE 4. Light photomicrographs of hearts in rats (a-f). (a) Hearts of rats from the negative control group showing normal cardiac myocytes. (b) Hearts of rats from the positive control group showing the vacuolation of cardiac myocytes, myocarditis, focal necrosis of cardiac myocytes associated with inflammatory cell infiltration, intermuscular oedema and hemorrhage. (c) Hearts of rats from the hypercholesterolemic group which was given the rosuvastatin showing the focal necrosis of cardiac myocytes associated with inflammatory cell infiltration and intermuscular oedema. (d) Hearts of rats from the hypercholesterolemic group which was given the ME showing few inflammatory cells infiltrating in between cardiac myocytes, the congestion of myocardial blood vessels and inter-muscular oedema. (e) Hearts of rats from the hypercholesterolemic group which was given the EAE showing focal myocarditis, intermuscular inflammatory cell infiltration and intermuscular oedema. (f) Hearts of rats from the hypercholesterolemic group which was given the mixture of the two extracts showing intermuscular oedema $(\mathrm{H}$ \& E X 400).

(a)

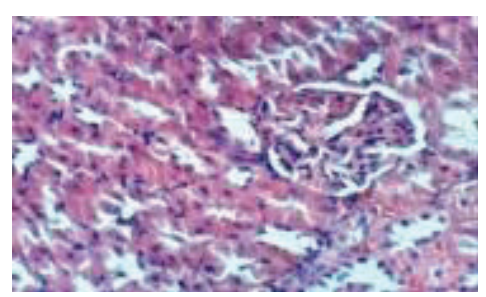

(d)

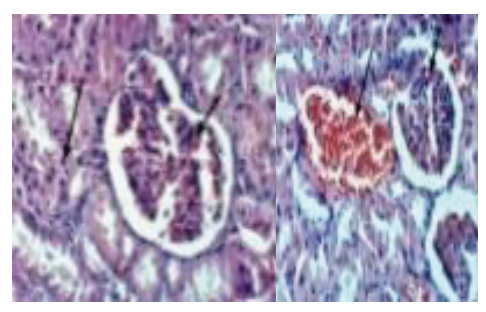

(b)

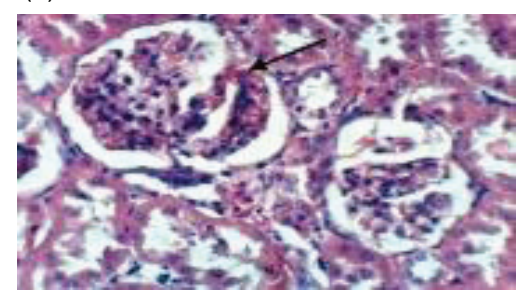

(e)

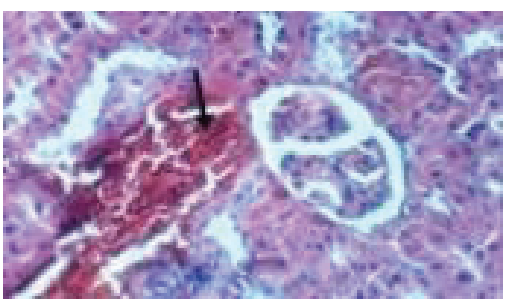

(c)

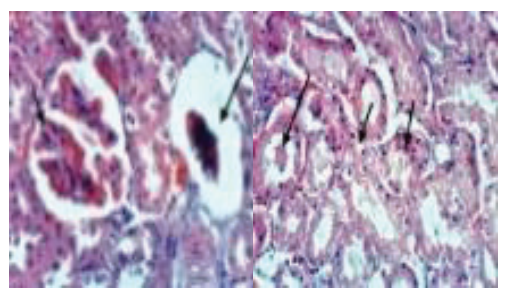

(f)

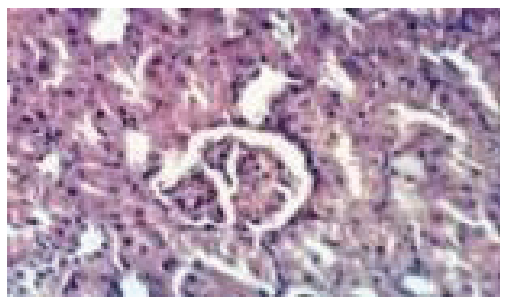

FIGURE 5. Light photomicrographs of kidneys in rats (a-f). (a) Kidneys of rats from the negative control group showing the normal histological structure of renal parenchyma. (b) Kidneys of rats from the positive control group showing the congestion and atrophy of the glomerular tuft with the distension of Bowman's space, vacuolation of renal epithelium, pyknosis of their nuclei and the presence of protein cast in the lumen of renal tubules. (c) Kidneys of rats from the hypercholesterolemic group which was given the rosuvastatin showing the congestion of the glomerular tuft. (d) Kidneys of rats from the hypercholesterolemic group which was given the ME showing hypertrophy and the congestion of the glomerular tuft and renal blood vessel and the necrosis of the epithelial lining of some renal tubules. (e) Kidneys of rats from the hypercholesterolemic group which was given the EAE showing the congestion of renal blood vessels. (f) Kidneys of rats from the hypercholesterolemic group which was given the mixture of the two extracts showing no histopathological changes (H \& E X 400). 
(a)

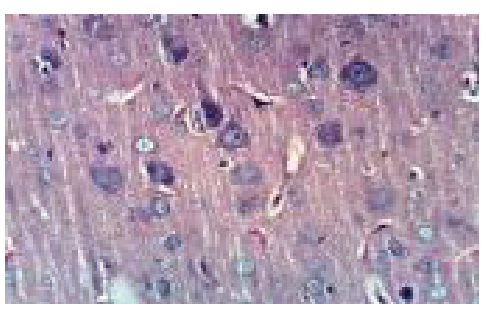

(d)

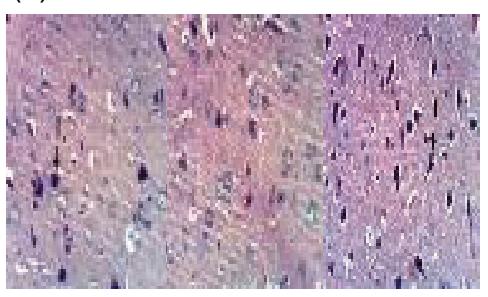

(b)

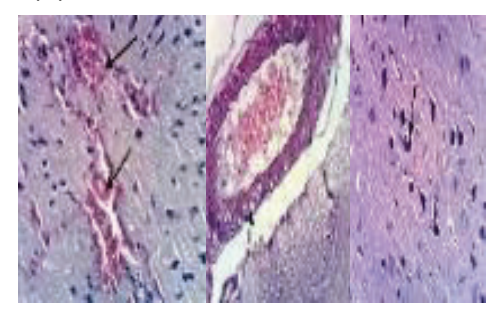

(e)

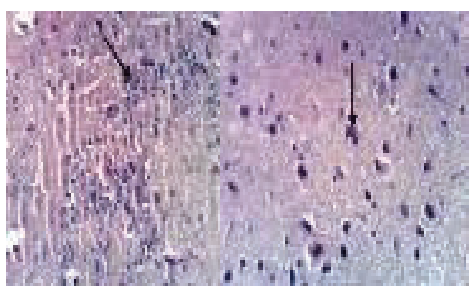

(c)

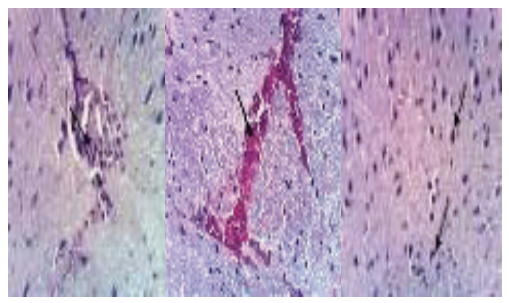

(f)

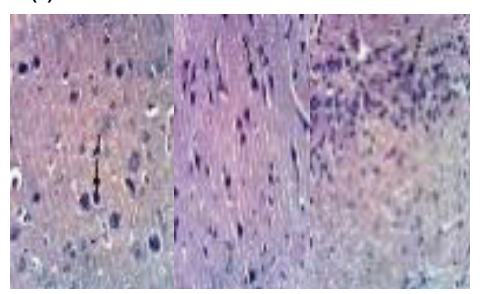

FIGURE 6. Light photomicrographs of brains in rats (a-f). (a) Brains of rats from the negative control group showing no histopathological change. (b) Brains of rats from the positive control group showing focal cerebral hemorrhage, the vacuolation of the tunica media of meningeal blood vessels and the neuronophagia of necrotic neurons. (c) Brains of rats from the hypercholesterolemic group which was given the rosuvastatin showing perivascular cuffing with inflammatory cells, focal cerebral hemorrhage and the neuronophagia of necrotic neurons. (d) Brains of rats from the hypercholesterolemic group which was given the ME showing the necrosis of some neurons \& neuronophagia of necrotic neurons. (e) Brains of rats from the hypercholesterolemic group which was given the EAE showing focal gliosis and the neuronophagia of necrotic neurons. (f) Brains of rats from the hypercholesterolemic group which was given the mixture of the two extracts showing the necrosis of some neurons, neuronophagia of necrotic neurons and focal gliosis (H \& E X 400).

heart, the kidney and the brain were in agreement with the results of biochemical markers and even reinforced them. Thus, no deterioration in any of the examined organs was observed when using any of the extracts either the methyl extract or the EAE or the mixture of both of them. There was, however, an improvement in the kidney and the liver where the hyperplasia of biliary epithelium with fibroplasia in the portal triad of the liver, which was noticed in the positive control group, disappeared. It is worth mentioning that all the histopathological changes in the kidney that were detected in the positive control group disappeared in the group of rats that was given the mixture of the two extracts. In case of the heart and the brain no deterioration was reported for the same three groups but a slight improvement was recorded compared to the positive control group.

\section{CONCLUSION}

From the obtained data, it can be concluded that the newly isolated SLs, which are of natural source, are potent hypocholesterolemic compounds. The obtained extracts of SLs not only lowered cholesterol but also adjusted the HDL-C and the LDL-C fractions, and lowered the risk for coronary heart disease, as documented by the decreased A.I, and also normalized the increased activity of the liver enzymes due to hypercholesterolemia better than rosuvastatin. In addition, the obtained SLs are safe, economical and of a natural source. However, further investigation is needed to determine the exact mechanism for lowering the total cholesterol and increasing the HDL-C by these extracts. Also, trails in human must be carried out in order to enable the use of these compounds as hypocholesterolemic drugs.

\section{ACKNOWLEDGEMENTS}

The authors would like to express their gratitude for the financial support given by the National Research Centre, Egypt (Project no.10130105). Also, authors would like to thank the scientific role of the pathologist; Prof. Dr. Kawkab Abd-elaziz, Professor of Pathology, Faculty of Veterinary Medicine, Cairo University for conducting the histopathological examination.

\section{REFERENCES}

Abreu IC, Guerra JFdC, Pereira RR, Silva M, Lima WGd, Silva ME, Pedrosa ML. 2014. Hypercholesterolemic diet induces hepatic steatosis and alterations in mRNA expression of NADPH oxidase in rat livers. Arq. Bras. Endocrinol. Metabol. 58, 251-259. https://doi. org/10.1590/0004-2730000002831

Aebi H. 1984. Catalase in vitro. Methods Enzymol. 105, 121-126. https://doi.org/10.1016/S0076-6879(84)05016-3

Anila L, Vijayalakshmi N. 2003. Antioxidant action of flavonoids from Mangifera indica and Emblica officinalis in hypercholesterolemic rats. Food Chem. 83, 569-574. https:// doi.org/10.1016/S0308-8146(03)00155-9 
Betke K, Savelsberg W. 1950. Stufenphotometrisho Hemoglobin estimmung mittels cyanohemoglobin. Z. Biochem. 320, 431.

Bose M, Lambert JD, Ju J, Reuhl KR, Shapses SA, Yang CS. 2008. The major green tea polyphenol,(-)-epigallocatechin-3-gallate, inhibits obesity, metabolic syndrome, and fatty liver disease in high-fat-fed mice. J. Nutr. 138, $1677-1683$.

Cha JH, Kim SR, Kang HJ, Kim MH, Ha AW, Kim WK. 2016. Corn silk extract improves cholesterol metabolism in C57BL/6J mouse fed high-fat diets. Nutr. Res. Pract. 10, 501-506. https://doi.org/10.4162/nrp.2016.10.5.501

Daverey A, Pakshirajan K. 2009. Production, characterization, and properties of sophorolipids from the yeast Candida bombicola using a low-cost fermentative medium. Appl. Biochem. Biotechnol. 158, 663-674. https://doi.org/10.1007/ s12010-008-8449-Z

Dobiášová M. 2004. Atherogenic Index of Plasma [Log(Triglycerides/HDL-Cholesterol)]: Theoretical and Practical Implications. Clin. Chem. 50, 113-115. http://doi. org/10.1373/clinchem.2004.033175

Draper H, Hadley M. 1990. Malondialdehyde determination as index of lipid Peroxidation. Methods Enzymol. 186, 421-431. https://doi.org/10.1016/0076-6879(90)86135-I

Fassini PG, Noda RW, Ferreira ES, Silva MA, Neves VA, Demonte A. 2011. Soybean glycinin improves HDL-C and suppresses the effects of rosuvastatin on hypercholesterolemic rats. Lipids Health Dis. 10, 1. https://doi. org/10.1186/1476-511X-10-165

Fawcett J, Scott J. 1960. A rapid and precise method for the determination of urea. J. Clin. Pathol. 13, 156-159. https:// doi.org/10.1136/jcp.13.2.156

Fernandez ML, West KL. 2005. Mechanisms by which Dietary Fatty Acids Modulate Plasma Lipids 1. J. Nutrit. 135, 2075-2078.

Ferreira ES, Amaral ALS, Demonte A, Zanelli CF, Capraro J, Duranti M, Neves VA. 2015. Hypocholesterolaemic effect of rat-administered oral doses of the isolated $7 \mathrm{~S}$ globulins from cowpeas and adzuki beans. J. Nutr. Sci. 4, e7. https:// doi.org/10.1017/jns.2014.70

Goodman, AG, Goodman, LS, Gilman, A. 1980. Principples of toxicology. In The Pharmacological Basis of Therapeutics. Goodman and Gilman (eds.), $6^{\text {th }}$ ed., New York: Macmillan Publishing Co., Inc. 1980., pp: 1602-1615.

Graveline D. 2015. Adverse Effects of statin drugs: a physician patient's perspective. J. Am. Phys. Surg. 20, 7-11.

Grove TH. 1979. Effect of reagent $\mathrm{pH}$ on determination of high-density lipoprotein cholesterol by precipitation with sodium phosphotungstate-magnesium. Clin. Chem. 25, $560-564$.

Haba E, Espuny M, Busquets M, Manresa A. 2000. Screening and production of rhamnolipids by Pseudomonas aeruginosa 47T2 NCIB 40044 from waste frying oils. J. Appl. Microbiol. 88, 379-387. https://doi. org/10.1046/j.1365-2672.2000.00961.x

Henry R, Chiamori M, Golub O, Berkman S. 1960. Revised spectrophotometric methods for the determination of glutamate oxaloacetic transaminase, glutamic pyruvate transaminase and lactic acid dehydrogenase. Am. J. Clin. Pathol. 34, 381-398.

Ito S, Inoue S. 1982. Sophorolipids from Torulopsis bombicola: possible relation to alkane uptake. Appl. Environ. Microbiol. 43, 1278-1283.

Jegadeesh R, Hariprasath L, Kumaresan K, Raaman N. 2014. In vitro Antioxidant and Antibacterial Activities of Fractionized Extracts of Edible Mushroom Pleurotus djamor var. roseus. J. Academ. Indust. Res. 3, 202.

Jiangwei M, Zengyong Q, Xia X. 2011. Aqueous extract of Astragalus mongholicus ameliorates high cholesterol diet induced oxidative injury in experimental rats models. $J$. Med. Plant. Res. 5, 855-858.

Jiménez-Peñalver P, Gea T, Sánchez A, Font X. 2016. Production of sophorolipids from winterization oil cake by solid-state fermentation: Optimization, monitoring and effect of mixing. Biochem. Eng. J. 115, 93-100. https://doi.org/10.1016/j. bej.2016.08.006
Kassem SS, Mahmoud H, Abdel-Kader M, El-Shobaki F. 2011. Evaluation of the Health Value of some Beverages Prepared from Vegetable and Fruit Wastes. J. Am. Sci. 7, 328-339.

Kobayashi M, Magishi N, Matsushita H, Hashimoto T, Fujimoto M, Suzuki M, Tsuji K, Saito M, Inoue E, Yoshikawa Y. 2008. Hypolipidemic effect of Shoyu polysaccharides from soy sauce in animals and humans. Int. J. Mol. Med. 22, 565.

Kris-Etherton PM, Yu S. 1997. Individual fatty acid effects on plasma lipids and lipoproteins: human studies. Am. J. Clin. Nutr. 65, 1628S-1644S.

Kuwabara T, Han K-H, Hashimoto N, Yamauchi H, Shimada K-I, Sekikawa M, Fukushima M. 2007. Tartary buckwheat sprout powder lowers plasma cholesterol level in rats. $J$. Nutr. Sci. Vitaminol. 53, 501-507. https://doi.org/10.3177/ jnsv.53.501

Mahmoud MH, Kassem SS, Abdel-Kader MM, El-Shobaki F. 2011. HOW TO REDUCE WEIGHT AND KEEP HEALTHY. Int. J. Academic Res. 3, 126-132.

Meiattini F, Prencipe L, Bardelli F, Giannini G, Tarli P. 1978. The 4-hydroxybenzoate/4-aminophenazone chromogenic system used in the enzymic determination of serum cholesterol. Clin. Chem. 24, 2161-2165.

Mohamed DA, El-Hariri D, Al-Okbi SY. 2005. Impact of feeding bread enriched with flaxseed on plasma profile of hyperlipidemic rats-a short report. Pol. J. Food Nutr. Sci. 14, 431.

Montilla P, Espejo I, Munoz M, Bujalance I, Munoz-Castaneda J, Túnez I. 2004. Effect of red wine on oxidative stress and hypercholesterolemia induced by feeding a high-cholesterol diet in rat. J. Physiol. Biochem. 60, 259-264. https:// doi.org/10.1007/BF03167071

Murray RL. 1984. Creatinine, In Clinical Chemistry, Theory, Analysis and Correlation. Kaplan LA and Pesce AJ (Eds.). CV Mosby Co., St. Louis, pp.1247-1253.

Nishikimi M, Rao NA, Yagi K. 1972. The occurrence of superoxide anion in the reaction of reduced phenazine methosulfate and molecular oxygen. Biochem. Biophys. Res. Commun. 46, 849-854. https://doi.org/10.1016/ S0006-291X(72)80218-3

Nissen NI, Ranløv P, Weis-Fogh J. 1965. Evaluation of four different serum enzymes in the diagnosis of acute myocardial infarction. Brit. Heart, J. 27, 520. https://doi.org/10.1136/ hrt.27.4.520

Oyedemi S, Bradley G, Afolayan A. 2010. In-vitro and-vivo antioxidant activities of aqueous extract of Strychnos henningsii Gilg. Afr. J. Pharm. Pharmacol. 4, 070-078.

Paglia DE, Valentine WN. 1967. Studies on the quantitative and qualitative characterization of erythrocyte glutathione peroxidase. J. Lab. Clin. Med. 70, 158-169.

Parekh VJ, Pandit AB. 2012. Solid State Fermentation (SSF) for the Production of Sophorolipids from Starmerella bombicola NRRL Y-17069 using glucose, wheat bran and oleic acid. Curr. Trends Biotechnol. Pharm. 6, 418-424.

Pincus M, Schaffner J. 1996. Assessment of liver function in clinical diagnosis and management by laboratory methods. Saunders, Philadelphia.

Price NP, Ray KJ, Vermillion KE, Dunlap CA, Kurtzman CP. 2012. Structural characterization of novel sophorolipid biosurfactants from a newly identified species of Candida yeast. Carbohydr. Res. 348, 33-41. https://doi.org/10.1016/j. carres.2011.07.016

Rahman K, Rahman TJ, McClean S, Marchant R, Banat IM. 2002. Rhamnolipid Biosurfactant Production by Strains of Pseudomonas aeruginosa Using Low-Cost Raw Materials. Biotechnol. Prog. 18, 1277-1281. https://doi.org/10.1021/ bp020071x

Rashad M, Al-Kashef A, Nooman M, El-din-Mahmoud A. 2014b. Co-utilization of motor oil waste and sunflower oil cake on the production of new sophorolipids by Candida bombicola NRRL Y-17069. Res. J. Pharm. Biol. Chem. Sci. 5, 1515-1528.

Rashad MM, Nooman M, Ali M, Al-Kashef A, Mahmoud A. 2014a. Production, characterization and anticancer activity of Candida bombicola sophorolipids by means of 
solid state fermentation of sunflower oil cake and soybean oil. Grasas Aceites 65, e017. https://doi.org/10.3989/ gya. 098413

Reeves PG, Nielsen FH, Fahey Jr GC. 1993. AIN-93 purified diets for laboratory rodents: final report of the American Institute of Nutrition ad hoc writing committee on the reformulation of the AIN-76A rodent diet. J. Nutr. 123, 1939-1951.

Rideout TC, Harding SV, Marinangeli CP, Jones PJ 2010 Combination drug-diet therapies for dyslipidemia. Translational Res. 155, 220-227. https://doi.org/10.1016/j. trsl.2009.12.005

Samarghandian S, Hadjzadeh M-A-R, Davari AS, Abachi M. 2011. Reduction of serum cholesterol in hypercholesterolemic rats by Guar gum. Avicenna J. Phytomed. 1, 36-42.

Scheletter G, Nussel E. 1975. Quantitative enzymatic Colorimetric determination of triglycerides in serum or plasma. Arbeitsmed Sozialmed Pracentimed. 10, 25.

Srinivasan K, Sambaiah K. 1990. The effect of spices on cholesterol 7 alpha-hydroxylase activity and on serum and hepatic cholesterol levels in the rat. International journal for vitamin and nutrition research. Internationale Zeitschrift fur Vitamin-und Ernahrungsforschung. Int. J. Vitam. Nutr. Res. 61, 364-369.

Trinder P. 1969. Determination of glucose in blood using glucose oxidase with an alternative oxygen acceptor.
Ann. Clin. Biochem. 6, 24-27. https://doi.org/10.1177/ 000456326900600108

Uhegbu FO, Ugbogu AE, Nwoku KC, Ude VC. 2013. Effect of Soybean Oil Supplemented Diet on Fatty Acid Level and Lipid Profile of Albino Rats. Brit. J. Pharmacol. Toxicol. 4, 158-162.

Üstun G, Kent L, Cekin N, Civelekoglu H. 1990. Investigation of the technological properties of Nigella sativa (black cumin) seed oil. J. Am. Oil. Chem. Soc. 67, 958-960. https://doi. org/10.1007/BF02541857

Van Hamme JD, Singh A, Ward OP. 2006. Physiological aspects: Part 1 in a series of papers devoted to surfactants in microbiology and biotechnology. Biotechnol. Adv. 24, 604-620. https://doi.org/10.1016/j.biotechadv.2006.08.001

Wang C, Ng T, Yuan F, Liu Z, Liu F. 2007. Induction of apoptosis in human leukemia K562 cells by cyclic lipopeptide from Bacillus subtilis natto T-2. Peptides 28, 1344-1350. https://doi.org/10.1016/j.peptides.2007.06.014

Warnick GR, Knopp RH, Fitzpatrick V, Branson L. 1990 Estimating low-density lipoprotein cholesterol by the Friedewald equation is adequate for classifying patients on the basis of nationally recommended cutpoints. Clin. Chem. 36, 15-19.

Wickerham LJ. 1951. Taxonomy of yeasts, in US Department of Agriculture Technical Bulletin, No. 1029, Washington, pp. 1-56. 